IZA DP No. 4590

The Economic Progress of American Jewry:

From 18th Century Merchants to

21st Century Professionals

Barry R. Chiswick

November 2009 


\title{
The Economic Progress of American Jewry: From 18th Century Merchants to 21st Century Professionals
}

\author{
Barry R. Chiswick \\ University of Illinois at Chicago \\ and IZA
}

Discussion Paper No. 4590

November 2009

\author{
IZA \\ P.O. Box 7240 \\ 53072 Bonn \\ Germany \\ Phone: +49-228-3894-0 \\ Fax: +49-228-3894-180 \\ E-mail: iza@iza.org
}

Any opinions expressed here are those of the author(s) and not those of IZA. Research published in this series may include views on policy, but the institute itself takes no institutional policy positions.

The Institute for the Study of Labor (IZA) in Bonn is a local and virtual international research center and a place of communication between science, politics and business. IZA is an independent nonprofit organization supported by Deutsche Post Foundation. The center is associated with the University of Bonn and offers a stimulating research environment through its international network, workshops and conferences, data service, project support, research visits and doctoral program. IZA engages in (i) original and internationally competitive research in all fields of labor economics, (ii) development of policy concepts, and (iii) dissemination of research results and concepts to the interested public.

IZA Discussion Papers often represent preliminary work and are circulated to encourage discussion. Citation of such a paper should account for its provisional character. A revised version may be available directly from the author. 
IZA Discussion Paper No. 4590

November 2009

\section{ABSTRACT}

\section{The Economic Progress of American Jewry: From 18th Century Merchants to 21st Century Professionals*}

This paper tracks the economic status of American Jewry over the past three centuries. It relies on qualitative material in the early period and quantitative data since 1890 . The primary focus is on the occupational status of Jewish men and women, compared to non-Jews, with additional analyses of earnings, self-employment, and wealth. The Jews in Colonial America, many of Sephardic origin, disproportionately lived in the east coast seaports and were engaged in international trade and finance. The mid-19th century German Jewish immigrants settled throughout the country; often beginning as itinerant peddlers, they advanced to small businesses, and some to not so small businesses in the retail trade. The Yiddish-speaking Eastern European and Russian Jewish immigrants, who arrived primarily in the four decades starting in 1881, are the ancestors of most contemporary American Jews. Starting in operative, craft and laborer jobs in small scale manufacturing or in retail trade in the northern and midwestern industrial cities, they experienced rapid economic advancement. Over the course of the 20th century their descendants achieved very impressive improvements in earnings and occupational status, attaining significantly higher levels than those of the nonJewish white population. By the year 2000, 53 percent of Jewish men compared to 20 percent of white non-Jewish men were in professional occupations. Among working women in 2000, 51 percent of the Jewish women and 28 percent of non-Jewish white women were in professional jobs. Differences by gender were smaller than differences by religion. Other determinants of earnings the same, including schooling, American Jewish men earned about 16 percent more than other white men, an advantage that is about 8 percent when major occupational group is also held constant. American Jews, from the earliest period to the present, have had high rates of self-employment compared to the non-farm white population of the United States. The nature of this self-employment has changed over time, and currently includes many self-employed professionals. The high level of human wealth of contemporary American Jews is not at the expense of non-human wealth. Overall, and even when other variables including schooling are held constant, Jews have higher levels of wealth and higher rates of wealth accumulation than other religious groups. In summary, over the 350 years since the first Jews settled in what is now the United States, American Jews have consistently demonstrated a very high level of economic achievement.

JEL Classification: J15, J24, J31, J61, J62, N31, N32, Z12

Keywords: Jews, immigrants, occupations, earnings, self-employment, wealth

Corresponding author:

Barry R. Chiswick

Department of Economics

University of Illinois at Chicago

601 S. Morgan Street

Chicago, IL 60607-7121

USA

E-mail: brchis@uic.edu

${ }^{*}$ I appreciate the comments on an earlier draft from Carmel U. Chiswick and Evelyn Lehrer. 
Other determinants of earnings the same, including schooling, American Jewish men earned about 16 percent more than other white men, an advantage that is about 8 percent when major occupational group is also held constant.

American Jews, from the earliest period to the present, have had high rates of selfemployment compared to the non-farm white population of the United States. The nature of this self-employment has changed over time, and currently includes many self-employed professionals.

The high level of human wealth of contemporary American Jews is not at the expense of non-human wealth. Overall, and even when other variables including schooling are held constant, Jews have higher levels of wealth and higher rates of wealth accumulation than other religious groups.

In summary, over the 350 years since the first Jews settled in what is now the United States, American Jews have consistently demonstrated a very high level of economic achievement. 


\section{Introduction}

The American Jewish community has experienced a remarkable economic advancement from the $18^{\text {th }}$ century to the present, both in absolute terms and relative to the non-Jewish population of the United States. It is an achievement that is unprecedented in terms of the various racial, ethnic, and religious groups that compromise the American population. It may also be unprecedented in terms of world-wide modern Jewish history. ${ }^{1}$

Most contemporary American Jews are the descendants of the mass migration of Jews who immigrated from Eastern Europe and Russia during the period 1881 to 1924, when immigration restrictions virtually ended, for several decades, migration from Southern and Eastern Europe. At arrival these Jewish immigrants were Yiddish speakers with at best little formal schooling, who worked primarily in craft, operative and laborer jobs in small establishments in light manufacturing or in retail trade, and were characterized by having low earnings. In contrast, their descendants are now nearly fully integrated into the American economic mainstream, with high levels of proficiency in English, high occupational levels (mainly professionals and mangers), high earnings, and high levels of wealth compared to other Americans.

1 The American Jewish community, which currently comprises two percent of the US population, currently accounts for about 40 percent of world Jewry, with another 40 percent living in Israel, and the remaining 20 percent in other Diaspora countries (DellaPergola, 2003, p. 597).

For studies of the economic achievement of Jews in several Diaspora countries, see for example, Elazar and Medding (1983), Prais and Schmool (1975), Darvish (1985), Syrquin (1985), and Tomes (1983). 
This paper will examine the economic progress of American Jews using quantitative data wherever possible. Because of the greater availability of data on occupation than on earnings or wealth, the focus will be on occupational status. A person's occupation is determined by many factors, including educational level, labor market experience, decision making skills, discriminatory barriers, and efforts to find niches in the economy to minimize the adverse effects of discrimination. Occupational status is also one of the most important determinants of income from the labor market. For most families, both Jewish and non-Jewish, income from labor market activities is the primary source of family or household income and wealth, and hence of their ability to purchase goods and services and to obtain their standard of living.

It is not as easy to study the economic attainment of groups defined by religion, such as Jews, as it is to do so for many other racial and ethnic groups. The decennial Census of the United States, for example, has long been a major source of data to study occupational attainment and, since the 1940 Census, the earnings of minority groups. However, the Census has never asked religion, and responses to the question on ancestry (asked since 1980) that reveal a respondent's religion are masked (U.S. Bureau of the Census, 1989). The Census Office/Census Bureau did conduct two surveys that permit the identification of Jews that are discussed below. But other indirect techniques, also discussed below, can be used as proxy identifiers of Jews in some Censuses. Other US government surveys and privately conducted surveys sometimes include a question on religion, but since Jews are a small proportion of the population (at the peak less than four percent of the US population in 1940, about two percent today) the sample sizes for Jews in these data sets are often too small for meaningful statistical analyses. Yet, where appropriate, analyses of data from these sources are reported. 


\section{Jews in the Colonial Period}

The American Jewish community has experienced waves of immigration over the past three and a half centuries, since the first Jewish community was established in 1654 in what was the Dutch colony of New Amsterdam (New York City) by a small group of Sephardic Jews fleeing the spread of the Inquisition as Portugal took over the Dutch colony in Racife, Brazil (Marcus, 1970, Volume II, Part IV, pp. 518-852). ${ }^{2}$ These first settlers were followed during the American colonial period by small numbers of other Sephardic Jews and German Jews who also settled in east coast seaport cities. ${ }^{3}$ Although systematic quantitative data apparently do not exist regarding their economic status, the qualitative material indicates that they became well established middle class, urban residence.

Many of the Jewish immigrants to Colonial America arrived as indentured servants or were "redeemed" at arrival by their families already in America. They quickly joined the mainstream of the Jewish community. The Jews were typically shopkeepers, merchants and shippers living in the tidewater seaport cities. Although some were craftsmen (artisans), very few were farmers, laborers, or professionals. Wealthier than the average American, there was a virtual absence of the very poor and the very wealthy. The Jewish merchants engaged in local, interior, coastal, and international (primarily with England and the Caribbean) trade and finance,

\footnotetext{
${ }^{2}$ For a detailed analysis of Jews in Colonial America, see the three volume study, Marcus, 1970. For a brief discussion of Jews in Colonial America see Sarna, 2004, Chapter 1.

For a study of the growth of the American Jewish population from colonial times to the late $20^{\text {th }}$ century, see Marcus, 1990.

${ }^{3}$ Sarna reports estimates that by 1776 , there were between 1,000 and 2,500 Jews in the United States, that is, 0.4 to 1.0 Jews per thousand population (Sarna, 2004, p. 375). Marcus (1970, Volume II, pp.522) suggests that during the 1700s there were two to three thousand Jews.
} 
and, as such, most were self-employed in clerical and managerial occupations. These were relatively skilled occupations at that time as literacy and numeracy were generally required.

The historian Jacob R. Marcus writes that the international trade was facilitated by their "skill, experience and contacts with Jews in other commercial centers, particularly in the West Indies” (Marcus, 1970, Volume II, pp. 843). Moreover he notes: “Though a very small percentage of merchants, the Jews were merchants, and a progressive and enterprising group of merchants at that” (Marcus, 1970, Volume II, pp. 844, italics in original). And that: “Then, as today, an upthrusting socioeconomic mobility was characteristic of American Jewish life” (Marcus, 1970, Volume II, pp. 838).

\section{German Jews}

Although a small number of Ashkenazic Jews arrived in the United States before the 1840's, larger numbers started coming in that decade. Changes in Central Europe, in particular, tensions associated with political ideas and economic upheavals due to changes in the structure of their economies and recessions in the emerging industrial sectors. Together with US economic development and growth, this brought to the United States an increased number of immigrants from Central Europe, in particular from the German speaking areas, during the 1840’s through the 1860’s (Kohler (1901), Lestschinsky (1966), Gartner (1983), and Barkai $(1986))^{4}$

Picking up the occupations many of them had in Europe, the German Jewish immigrants concentrated in retail trade, and to a lesser degree, wholesale trade. Many became peddlers, as they were in Europe, literally carrying their wares on their backs in all regions of the country. As

\footnotetext{
${ }^{4}$ Sarna reports estimates that the Jewish population of the United States increased from about 15,000 (nearly one Jew per thousand population) to 230,000 to 300,000 in 1880 (5 to 6 Jews per thousand of the US population) (Sarna, 2004, p. 375).
} 
they prospered, they would acquire a pack animal or horse and wagon. Soon they settled down in cities and towns, large and small, and opened small retail establishments throughout the United States. This was surely an easier life than being on the road most of the time (Goodman, 1951). They were not as geographically concentrated as were the earlier Colonial Jews (Atlantic coast seaport cities) or the later waves of East European/Russian Jews (New York, Chicago and other major industrial cities in the North and Midwest). Indeed, while German Jews settled as merchants in the Southern and Western states, and in small towns across the US, few East European/Russian Jews moved there.

Some of these German Jewish merchants experienced considerable success, and expanded the size and number of their businesses. While most did not become department store magnates, some did, creating such well known department stores in various parts of the country as Bloomingdales, Gimbels, Saks, Goldwaters, and Nieman-Marcus, among others. Most, however, remained as small operators in major cities, small cities, and towns across the country. Indeed, outside of New York City, the contact that most non-Jewish Americans would have with Jews was in the latter's retail establishments, primarily grocery, dry goods, and small department stores.

The earliest systematic quantitative data on the economic status of American Jews appears to be from a survey "Vital Statistics of Jews in the United States” conducted in 1890 (Billings, 1890). This is better known as the Billings Report, after John Shaw Billings, the head of the project and the author of the Report. ${ }^{5}$ It is apparently the only survey exclusively of Jews conducted by the Census Office, or its successor, the Census Bureau. Aware of the increasing immigration of Eastern European and Russian Jews in the 1880s and aware that there would be

\footnotetext{
${ }^{5}$ For an analysis of the Billings Report, see Chiswick 2001.
} 
no mechanism for identifying Jews in the 1890 Census, this special survey was undertaken. It was conducted with the assistance of Adolphus Solomons, a prominent member of the Jewish community who was a businessman, philanthropist, community leader, and co-founder with Clara Barton of the American Red Cross. ${ }^{6}$ At Solomons’ invitation Rabbis and presidents of Jewish congregations provided the names of Jews who were interviewed. The intent was to collect data on the vital statistics (births, deaths, illnesses) of 10,000 Jewish households over the five year period, 1885 to 1890 . The Billings survey included a question on occupation, and the Report provides the first systematic quantitative data on the economic status of American Jews.

The law of unintended consequences came into play because only Jews in the US for at least five years prior to 1890 were to be interviewed. Most Jews in the US by 1885 were, in fact, German Jews. Although large scale Eastern European and Russian Jewish immigration began in the early 1880's it was only later that it turned into a mass immigration. The Billings Report indicates that of the Jews surveyed, 55 percent reported that their mother was born in Germany, while 21 percent reported that their mother was born in the US, 11 percent reported Russia or Poland, and for 13 percent it was another country or the country was not reported. The younger the respondent the more likely the mother was born in the United States, presumably primarily of German origin (Billings, 1890, Table II).

The data on the 1890 occupational attainment of the Jewish and non-Jewish men are instructive (Billings, 1890, Table IV; Chiswick, 2001, Table 3). Fully 57 percent of the Jewish men were in sales, another 20 percent in clerical occupations, and 12 percent in craft jobs, with 5 percent in professional jobs, and with only 2 percent in agriculture. By contrast, among white native-born men in general, as reported in the 1890 Census, only 2 percent were in sales, 6

\footnotetext{
${ }^{6}$ Solomons was born in New York City of parents born in England, but of Sephardic origin.
} 
percent in clerical jobs, 13 percent in craft occupations, 3 percent worked in profession occupations, and 46 percent worked in agriculture. ${ }^{7}$ Among the Jews in sales, most worked for themselves as peddlers, push-cart operators or owners of their own small retail outlets. Clearly, the Jewish men in the US in 1885, predominantly of German Jewish origins, had an occupational distribution distinct from the general population. As will be seen, this occupational pattern is also quite distinct from that of the East European and Russian Jewish immigrants who arrived in the US in the four decades from the early 1880's until the enactment of the immigration restrictions in the "national origins" quota system in 1921 and 1924.

\section{Occupations of East European Jewish Men: Prior to World War II}

Census data cannot be used to identify Jews, or develop proxy identifiers for Jews, until the 1900 Census. Sephardic Jews living in the US could not be distinguished from others in Census data in the early $19^{\text {th }}$ century, nor could the mid- $19^{\text {th }}$ century German Jewish immigrants be distinguished from other German immigrants. Although Russian and Russian/Polish places of birth were recorded in the 1890 Census, most of the original records of the first Census that would include many Jews from these origins were destroyed in a fire (Blake, 1996). Thus,

\footnotetext{
${ }^{7}$ To the extent possible in the analyses that follow Jews are compared to whites, since according to the National Jewish Population Survey and the NORC General Social Survey 98 percent of Jews report that their race is white. The economic advantage of Jews compared to non-Jews would be even greater if they were compared to others regardless of latter's race. The Jewish share of the population increased from a negligible proportion in 1880 to a peak of less than 4 percent prior to WWII and has since declined to about 2 percent. Thus, whether Jews are included or, where possible, excluded from the data on "non-Jewish" comparison groups has little impact on the results. Even in occupations in which Jews are disproportionately represented, they are a small minority of members of the occupation.

${ }^{8}$ The data on occupational attainment are drawn from Chiswick 1999 and B. Chiswick 2007.
} 
modern data files constructed from decennial Census records for other years cannot be created for the 1890 Census. ${ }^{9}$

As a result, the earliest Census in which Jews can be identified is 1900 by using a Russian or Russian/Polish birthplace or parental birthplace as a crude Jewish identifier. ${ }^{10}$ Another Jewish identifier that came into the Census in 1910 and remained through the 1970 Census is "mother tongue". ${ }^{11}$ Although the exact wording varied from Census to Census, the basic question was identifying a language other than or in addition to English that the respondent spoke at home when the respondent was a child. ${ }^{12}$ Yiddish, Hebrew, and Ladino can be used as Jewish identifiers in that those who reported one of these languages have a high probability of being Jewish, and few non-Jews would report these languages. ${ }^{13}$ Yet, the limitation of the Jewish mother tongue approach is that many Jews, particularly those from Germany and other parts of Western Europe, and especially those with parents born in the US, would not report any of these Jewish languages.

Using the Russian-origin technique (which of course includes non-Jews of Russian origin) and the Yiddish mother tongue technique (which, of course, misses many Jews) it is possible to identify Eastern European and Russian Jewish immigrants and their US-born children

\footnotetext{
${ }^{9}$ The 1890 data referred to above on the occupations of the general male population were from a Census Office volume published in 1897 (U.S. Census Office, 1897, pp. 118-119).

${ }^{10}$ For analyses of the validity of using the Russian origin method for identifying Jews, see Ritterband (1998) and Rosenthal (1975).

${ }^{11}$ For analyses of the validity of the "mother tongue” method of identifying Jews, see Korbin (1983) and Rosenwaike (1971).

${ }^{12}$ Since the 1980 Census of Population the language question refers to languages currently spoken at home.

${ }^{13}$ Originally only Yiddish was coded by the Census Bureau, but Hebrew and Ladino were later added to the codes. Ladino is the origin language of Sephardic Jews. The last time mother tongue was asked (1970 Census) very few respondents indicated either Hebrew or Ladino.
} 
from the turn of the century up to World War II. These techniques are of lesser value in the post WWII period, but some other data sources with direct Jewish identifiers are available. ${ }^{14}$

In 1910, for example, among adult Yiddish mother tongue immigrant men, 9.6 percent were in professional and managerial jobs, 27.1 percent in sales jobs, 31.7 percent in craft employment, and 22.3 percent in operative jobs. Few were in clerical (2.5 percent), service (2.4 percent), or laborer (3.6 percent) jobs, and negligible numbers were in agriculture. Among foreign-born men who were not Jewish, only 5.6 percent were in professional and managerial jobs, only 6.8 percent in sales, with 2.5 percent in craft, and 17.6 percent in operative jobs. Many worked as laborers (23.5 percent) or in agriculture (13.1 percent). The East European Jewish immigrants were in somewhat higher occupational categories than those of other immigrant men, nearly all of whom were also from Europe. ${ }^{15}$

The occupational differences by religion in 1910 are even greater when second generation Jewish men (born in the US with a Yiddish mother tongue and one or both parents foreign born) are compared with native-born white men. Among the Jewish men, identified by mother tongue, 16.1 percent were in professional and managerial jobs (two-thirds of whom were professionals), and many were in clerical jobs (20.3 percent). Sales employment was important (31.5 percent), but the blue collar jobs (service, craft, operative, laborer, and agriculture jobs) became less common (32.2 percent compared to 60.5 percent for the Jewish immigrant men).

\footnotetext{
${ }^{14}$ It is estimated that the Jewish population of the US increased to nearly one million in 1900 (about 1.3 percent of the US population), to nearly 5 million just prior to World War II (a peak of about 3.7 percent of the population) to about 5.3 million in 2000 (just under 2.0 percent of the population) (Sarna, 2004, p. 375). The slow growth of the Jewish population since the passage of immigration restrictions in the 1920's is due to both low immigration and a below replacement fertility rate.

${ }^{15}$ Douglas (1919, p 393) comments on the higher occupational status of Jewish immigrants as reported at entry into the United States. He notes that " ... the Jews are the most skilled of the newer races.”
} 
Among the native-born white men in 1910, 9.9 percent were professionals and managers, with only 16.3 percent in clerical and sales jobs, nearly half in the non-farm blue collar jobs (44.8 percent) and over a quarter in agriculture (28.7 percent).

Thus, in 1910 the East European Jewish men had occupational distributions very different from those of the primarily German Jews in 1890 (mainly sales and clerical), and they were more urban and higher skilled than non-Jewish men in 1910, whether native or foreignborn. And among the Jews, those born in the US compared to those born in Europe were more likely to be in white collar jobs that in general would have required a command of English.

This tendency toward white collar and professional employment is seen vividly in the 1940 Census data. Among the men born in the US who reported a Yiddish mother tongue, 14.9 percent were in professional and technical occupations, with 22.2 percent as managers. While clerical (14.6 percent) and sales (20.3 percent) jobs were still important, the blue collar jobs were clearly on the wane (27.3 percent). Among native-born white men, however, only 6.3 percent were professionals, 10.7 percent managers, 13.7 percent in sales and clerical jobs and fully 69.1 percent were still in blue collar jobs, including agriculture. Thus, by the eve of US entry into World War II, the US-born children of Yiddish speaking immigrants had achieved high rates of employment in professional occupations and were well on the road to abandoning the blue collar jobs held by their immigrant parents and grandparents.

\section{Occupations of Jewish Men: Post World War II ${ }^{16}$}

Identifying Jews in census data becomes more difficult in the first three Censuses after World War II, and impossible from the 1980 Census onward. Yiddish falls out of use, even among Jewish immigrants, and the question on parental birthplace is last asked in 1970. An

\footnotetext{
${ }^{16}$ The data on occupational attainment are drawn from Chiswick 1999 and B. Chiswick 2007.
} 
increasing proportion of Jews are third-generation Americans. For the ancestry question introduced in the 1980 Census, any response that indicates a person's religion is masked. ${ }^{17}$ Still, a combination of decennial Census data, and other data, can be used to track Jewish/non-Jewish occupational patterns. In 1990 and 2000/01, the National Jewish Population Survey (NJPS) can be used to identify Jewish occupational attainments. ${ }^{18}$

The Current Population Survey (CPS) has been conducted by the Census Bureau for the Bureau of Labor Statistics every month since 1947. The aim of the survey is to provide data on labor market developments. In March 1957 the CPS for the first and the only time included a direct question on religion. The tables created by the Census Bureau from this survey permit a direct comparison of the occupational attainment of Jews and other white men (U.S. Bureau of Census, 1958 and no date).

The professionalization of the adult male Jewish labor force continued, reaching 20.3 percent in 1957. Many were still in managerial jobs (35.1 percent); sales was still an important occupation (14.1 percent), while clerical jobs (8.0 percent), craft employment (18.9 percent), and blue collar employment (12.3 percent) all declined.

Among other white men, professional employment increased (to 10.3 percent) but not by as much as among Jews. Many fewer were in managerial jobs (13.6 percent) than among Jews. Similar proportions were in clerical jobs (7.1 percent), but a much smaller proportion were in sales (5.6 percent), while nearly two-thirds (63.4 percent) were in blue collar jobs.

\footnotetext{
${ }^{17}$ In the Census microdata file, any response to the ancestry question indicating a religion (e.g., Jewish, Catholic, Baptist, Mormon, etc) is given the same code. Thus, individual religions cannot be distinguished.

${ }^{18}$ Unfortunately there is no 2010 NJPS, nor are there plans for another National Jewish Population Survey.
} 
While non-Jewish white men experienced an increase in their occupational status from 1940 to 1957, Jews experienced a much sharper increase. Indeed, by 1957 one-in-five Jewish men were in a professional occupation, compared to only one-in-ten non-Jewish white men. Both patterns, improvements for non-Jewish men and greater gains for Jewish men, continued throughout the rest of the $20^{\text {th }}$ century.

The data on occupational attainment among Jewish men in the 2000/01 National Jewish Population Survey can be compared with that of non-Jewish white men in the 2000 Census of Population. Among Jews, over one half (53 percent) of the men were in professional occupations, with managerial jobs playing a much smaller role (14.8 percent) than in the past as Jews left managing small businesses. Sales remained important (18.5 percent), but clerical work declined (3.1 percent), while blue collar jobs (including service work) became even rarer among Jews (10.6 percent). Among all white men, professional employment increased, but to only 19.7 percent. Managerial jobs held steady (15.1 percent). Others were employed in sales (10.4 percent) and clerical jobs (6.0 percent). In spite of the declines in manufacturing and farm employment in the US economy, nearly half of white men were still employed in blue collar jobs (48.6 percent).

Thus in the last four decades of the $20^{\text {th }}$ century non-Jewish white men experienced improvements in their occupational status, but Jewish men both started at a higher level and experienced steeper improvements.

VI. Doctors, Lawyers, and Professors ${ }^{19}$

Given the importance of professional occupations among Jews, it is useful to examine the component occupations. In 1940, among second-generation Yiddish mother tongue men, 14.9

${ }^{19}$ The data on occupational categories among professionals are drawn from Chiswick 1999 and B. Chiswick 2007. 
percent were professionals, but of these 2.9 percentage points were in medicine (e.g., doctors and dentists), 3.5 percentage points in law (lawyers and judges), negligible numbers were college and university teachers, and 8.5 percentage points were in other professional occupations. This was a more intense concentration in independent professional practice, medicine and law, than among non-Jewish men. Among male native-born non-Jews, of the 6.3 percent professionals, 0.8 percentage points were in medicine, 0.5 percentage points in law, 0.2 percentage points in college and university teaching, and 4.8 percentage points in other professional jobs.

The General Social Survey (GSS) conducted nearly annually since 1972 by the National Opinion Research Center (NORC) includes a question on religion (Chiswick 1995). While each annual survey has too few Jews for statistically meaningful analyses, by aggregating the data across years sufficiently large samples of Jews can be developed. Using data from the NORC General Social Survey (1974-1986), 43 percent of Jewish men were professionals, with disproportionate numbers in medicine (8.3 percentage points) and law (5.6 percentage points), a peak of 4.9 percentage points as college and university teachers, while 24.2 percentage points (56 percent of the professionals) were in other professional occupations.

By the 2000/01 NJPS patterns has changed even further. While just over half (53 percent) of Jewish men were professionals, the share in independent professional practice had declined (4.8 percentage points in medicine, 5.3 percentage points in law), college and university teaching had declined (1.9 percentage points), and the share in other professions increased (41.0 percentage points). In contrast, among non-Jewish white men in 2000, while 19.7 percent were professionals, there were smaller proportions in medicine, law, and college and university teaching ( $0.9,1.1$, and 0.9 percentage points, respectively), while most were in other professions (16.8 percentage points). 
Prior to World War II professional opportunities for American Jews were limited (Dinnerstein 1994, Ritterband and Wechsler 1994, Alchian and Kessel 1962, Sarna 2004, Chapter 5, Chiswick 2009). Discrimination against Jews in professional jobs was common in most industries, but Jews sought niches in which they could secure professional careers. The problem was compounded by discrimination against Jews in access to the schooling needed to acquire professional credentials. While many young Jews went abroad to study medicine, this was not feasible for law. Jewish hospitals and Jewish law firms were established to provide employment opportunities. But elsewhere, including professional employment in colleges and universities, the opportunities were limited.

With the end of World War II there was a dramatic, yet gradual change in attitudes toward anti-semitic employment practices. One of the first sectors in which the barriers were relaxed was in higher education, in terms of both the admission of students and accepting Jews on the faculty. Jews, ever responsive to expanded opportunities, flocked into higher education. With expanded opportunities for employment in college and university jobs and the opening more widely of $\mathrm{PhD}$ programs, a greater number of Jews sought the $\mathrm{PhD}$, the de facto "union card” for a position in higher education. Indeed, $\mathrm{PhD}$ graduates who had distinctive Jewish surnames increased in the 1960's and early 1970's not only in absolute numbers, but also as a proportion of all PhD's awarded, but thereafter the absolute and relative number declined (Chiswick 2009) $^{20}$. So too did the number of Jewish men entering medicine and law. Yet, the total number and share of Jewish men in professional occupations increased. As discrimination

\footnotetext{
${ }^{20}$ Another proxy identifier for Jews is the Distinctive Jewish Name technique (see, Himmelfarb et al. 1983, Sheskin 1998). Name changes (which were not uncommon at or shortly after immigration to the US), intermarriage, and religious conversion both in and out of Judaism weaken the effectiveness of this technique. The data on PhDs awarded are drawn from Chiswick 2009.
} 
declined in other sectors of the economy in the last few decades of the $20^{\text {th }}$ century, Jews entered these other high-level occupations in larger numbers, thereby reducing their relative numbers in medicine, law and college and university teaching.

VII. Occupations of Jewish Women ${ }^{21}$

The occupational attainments of women in the early $20^{\text {th }}$ century are not particularly meaningful since so few married women worked in the labor market, and many women who did work for pay were young and usually not yet married. ${ }^{22}$ The choice of occupation of those who did work would have been influenced by their anticipating leaving the labor force. By the end of the $20^{\text {th }}$ century, however, women's labor force participation, even that of married women, had reached high levels, although Jewish women were less likely to work when their children were young and more likely to work before children were born or when they are older (Chiswick 1986, 1997a)..$^{23}$

The high occupational status of American Jews is not limited to men, as Jewish women also experienced impressive occupational achievements. Using the data from the 2000/01 NJPS and the 2000 Census information can be obtained on the occupational attainment of employed women. Among Jewish women 51.4 percent were in professional jobs, and 15.9 percent were in managerial jobs. Sales occupations were employing 12.9 percent and clerical jobs 12.1 percent, while the remaining 7.4 percent were in blue collar (including service) jobs. Among non-Jewish white women, 28.5 percent were professionals and 11.0 percent managers, 11.1 percent in sales,

${ }^{21}$ The data on the occupational attainment of women are drawn from B. Chiswick 2007.

${ }^{22}$ Adult Jewish women who were married with children at home had a lower labor supply than otherwise similar non-Jewish women throughout much of the $20^{\text {th }}$ century. For the early $20^{\text {th }}$ century, see Glenn 1990.

23 Jewish women appear to be at home making greater investments in the human capital of their sons and daughters than non-Jewish women. 
but a quarter (25.1 percent) were in clerical jobs. The blue collar sector employed nearly a quarter (24.4 percent).

Among Jews, the gender difference in occupations is quite small, especially if sales and clerical jobs are combined into one category, as men are more likely to be in sales and women in clerical positions (Hartman and Hartman 1996; Hartman and Hartman 2009). The gender differences are more striking among non-Jews, with especially high proportions of white women compared to white men in professional (including public school teaching) and clerical jobs. Yet the differences by religion are greater than the differences by gender. In particular, by the year 2000, half of employed Jewish men and half of employed Jewish women were working in professional occupations!

There is a tendency toward "positive assortative mating" in marriage. In simple terms, this means that men and women tend to marry those with similar characteristics, including race, religion, education, and occupation, among other characteristics. This raises the question as to the extent to which high occupational status Jewish men and women marry each other. Using data on employed married couples from the 2000/01 National Jewish Population Survey in which both are Jewish by religion, in 51 percent of these couples both spouses are in professional or managerial occupations (C. Chiswick 2007). The proportion is 50 percent among employed couples in which both are Jewish by religion, ethnicity, or background. The proportion declines to 46 percent among couples in which one spouse is Jewish by religion, ethnicity, or background and the other spouse is of any religion. This latter decline arises from the lower occupational status of those who are not Jewish even in Jewish/non-Jewish marriages. Thus, in about half of all married households in which at least one spouse is Jewish both the husband and the wife have jobs in high level occupations. 


\section{Self Employment}

Self-employment is another characteristic of the economic position of a population, although self-employment can range from being a self-employed (own-account) peddler to a selfemployed professional to owning a large retail or industrial establishment. The earliest systematic data on self-employment comes from the 1910 Census of Population and extends to the most recent Census (US Bureau of the Census (1989), B. Chiswick $(1999,2007)){ }^{24}$

In 1910, among the foreign-born Yiddish mother tongue men, 38.4 percent were selfemployed, even though there were few farmers among them. Self-employment was much lower (16.1 percent) among the second-generation Yiddish mother tongue men in 1910. Among nonJewish men, self-employment was lower among the foreign born (22.3 percent), and much higher among the native-born (35.5 percent), many of whom were self-employed farmers.

Self-employment among Jewish men increased by 1940 to 41.4 percent for immigrants and 27.0 percent among the second generation. Among the non-Jewish men there was no change among the immigrants (21.2 percent), but a decline among the native born (to 27.3 percent), reflecting the decline in the agriculture sector, especially the family farm.

According to the 1957 Current Population Survey data, with the direct Jewish identifier, nearly one-third of Jewish men were self-employed (31.9 percent), in contrast to half that ratio among the non-Jewish men (15.8 percent). The proportions were roughly the same in the 1970 Census data for white second-generation Americans, 31.9 percent for Jews and 14.1 percent for non-Jews.

Self-employment has since declined substantially for Jewish men, falling to 26.8 percent and 23.2 percent in the 1990 NJPS and 2000/01 NJPS, respectively. This is still much higher

\footnotetext{
${ }^{24}$ The published material from the 1890 Billings Report did not include information on selfemployment (Billings, 1890).
} 
than the rate of self-employment among non-Jewish white men, which remained steady in recent decades (14.1 percent in 1990, 14.0 percent in 2000).

Women are less likely to be reported as self-employed than men. Even among women, however, self-employment is greater among Jews, but the Jewish female self-employment rate declined from 14.0 percent in 1990 to 11.3 percent in 2000. In contrast, among non-Jewish white women it held steady at 8.6 percent in both years.

Although very few Jews in the US were in farming, Jews had very high self-employment rates that initially increased in the early $20^{\text {th }}$ century as workers become owners of small businesses, and then declined sharply in the second half of the $20^{\text {th }}$ century. The decline was associated with Jews leaving the ownership of small businesses and entering managerial and professional positions in larger firms as salaried workers. That Jews still have a higher propensity for self-employment is, in part, a shift from operating family owned retail and manufacturing firms to self-employed professional activities. The very high self-employment rate among native-born white non-Jewish men in the early $20^{\text {th }}$ century and the very large decline over the course of the $20^{\text {th }}$ century is largely due to the change in the nature and scope of the agricultural sector. $^{25}$

\section{Earnings of American Jewish Men}

Even more scarce than data that can be used for comparing Jewish and non-Jewish occupational status, is comparative data on earnings. Yet over the course of the $20^{\text {th }}$ century there are a few data sets that permit this comparison.

\footnotetext{
${ }^{25}$ In the 1890 Census, 46.2 percent of native-born non-Jewish white men worked in agriculture as farmers, farm owners and farm laborers. By 1990 among white men this had fallen to 3.6 percent (Chiswick, 1999).
} 
A question arises as to whether the rapid improvement in the occupational status of turnof-the-20 $0^{\text {th }}$ century East European and Russian Jewish immigrants reflected a preference for managerial and sales occupations in small businesses over wage and salary employment in other occupations that might have provided higher earnings. Data from the Dillingham Immigration Commission Report published in 1911 can shed light on this issue (US Immigration Commission 1911, Chiswick 1992). ${ }^{26}$

The Dillingham Commission conducted a survey in 1909 of production workers in selected mining and manufacturing industries, with an oversampling of industries with a heavy concentration of immigrants from Southern and Eastern Europe (Chiswick 1992). Jews were treated in the data as a separate race/ethnic group. Jewish immigrant men had, on average, weekly wages (\$13.30) that were 15 percent higher than other Southern and Eastern European immigrants (\$11.54), but they were lower by only 2 percent than those from Northwestern Europe and Canada (\$13.56) and lower by only 5 percent than the native-born $(\$ 13.98) .{ }^{27}$ Controlling statistically for several determinants of earnings (e.g., literacy, marital status, age, duration in the US, and region of US residence), the Jewish immigrant men earned about 15 percent more than all other male immigrants (coefficient $0.17, \mathrm{t}=2.70$ ), including more than both other Southern and Eastern European immigrants (coefficient 0.13, t = 2.3) and Northwest European immigrants (coefficient 0.18, $\mathrm{t}=1.6$ ).

\footnotetext{
${ }^{26}$ William P. Dillingham was an anti-immigrant Senator from Vermont who chaired the Commission. Volume 1 of the 41 volume report was the policy analysis which took a very dim view of Southern and East European immigrants. The Commission's report was instrumental in the enactment of legislation that resulted in the "national origins" quota system (legislation in 1921 and 1924) that drastically restricted immigration from Southern and Eastern Europe, including Russia, for four decades, until the 1965 Immigration Amendments.

27 The Dillingham Commission data differentiated between Russian origin and other Jews. There was no difference in earnings between the two groups.
} 
At arrival, Jewish men earned less than the native-born white men, but because their earnings increased sharply with duration in the United States they caught up with the native born at about 4.5 years duration in the US, beyond which the Jews had higher earnings than their native-born non-Jewish counterparts. Earnings increased more steeply with duration in the US among the Jewish immigrants than among other immigrants. This implies either greater investments in US-specific job training, a higher economic return from such training, or both.

The 1940 Census was the first Census to include a question on earnings or income (US Bureau of the Census, 1989). It asked for wage, salary, and commission income of those with earnings who were not self-employed. Jews could be identified by mother tongue. The average annual earnings among Jewish men was \$1,574 and among white non-Jewish men, \$1,321 (19.2 percent higher earnings). Other variables the same, however, male Jewish wage and salary workers earned 8.8 percent more than non-Jewish white men $(t=4.7)$. Thus, half of the gross differential is attributable to other variables (e.g., schooling, urban, northern residence, etc.) and about half remains unexplained (Chiswick, 1999).

The tables constructed from the March 1957 Current Population Survey, which included a question on religion, included data on median annual incomes among men (US Bureau of the Census, no date). Jews earned $\$ 4,900$, considerably more than the $\$ 3,728$ of white Protestant men (by 31 percent) and \$3,954 of Roman Catholic men (by 24 percent). The differences shrink when the data were limited to employed men living in urban areas and standardized for major occupational group. Then Jews earned 4.8 percent and 5.9 percent higher median income than white Protestant and Roman Catholic men, respectively. ${ }^{28}$

\footnotetext{
${ }^{28}$ For two reasons, the Jewish/non-Jewish earnings differential is smaller in the 1957 Current Population Survey than in the other data on earnings considered elsewhere in this section. When the Census Bureau standardized the data for major occupation group, it essentially held constant
} 
Using the data from the NORC General Social Survey, 1974 to 1986, Jews are found to have about 38 percent higher earnings ( $\$ 27,300$ for Jewish men compared to $\$ 19,800$ for other men) (Chiswick 1995). When statistical controls are introduced for several variables (including schooling level, urban residence, and marital status), the Jewish earnings advantage declines to 16 percent, with no obvious trend in the differential over the period.

Using the "mother tongue" technique for Yiddish, Hebrew, or Ladino among secondgeneration Americans in the 1970 Census, a subset of Jews can be distinguished from other second-generation white Americans (Chiswick, 1983). Other measured variables the same, Jewish men had a 16 percent earnings advantage $(\mathrm{t}=12.41)$ over comparable non-Jewish white men with parents born in the British Isles (the benchmark). ${ }^{29}$ All of the other parental birthplaces have earnings not significantly different from or significantly lower than those with parents from the British Isles, with one exception, those of Russian parentage who do not report a Jewish language as their mother tongue (coefficient $0.058, \mathrm{t}=4.65$ ). This latter group may include many Jews who are not identified as having a Jewish mother tongue. When major occupational categories are added to the earnings equation, Jewish men earn 10.2 percent more than second-generation white non-Jews $(t=8.0)$.

The regression analysis using second-generation white Americans in the 1970 Census also revealed two other characteristics of the Jews (defined by mother tongue) under study (Chiswick 1983). One is the larger payoff to education as measured by the coefficient on years

another important measure of labor market outcomes, namely, occupational attainment. This narrowed the Jewish/non-Jewish earnings differential. Because of the positive skewness in the distribution of earnings, it is likely that the relative difference in medians is smaller than the relative difference in means.

${ }^{29}$ The other variables include schooling, labor market experience, marital status, urban residence, residence in a southern state and parent's country of birth (Chiswick 1983). 
of schooling, even when occupational status is held constant. This suggests that Jews are more effective than others in converting schooling into earnings, providing a greater incentive to make these investments. The other is the larger elasticity of annual earnings with respect to weeks worked, suggesting a greater responsiveness of labor market behavior (employment) to economic incentives (wages).

\section{The "New" Russian Jewish Immigrants}

The $20^{\text {th }}$ century began and ended with the immigration to the US of Jews from the Russian Empire and from its later equivalent, the Former Soviet Union (FSU). The term "Russian Jews" in both periods was applied to those who came from Russia and the territories it occupied, including the Ukraine, the Baltic States, and the Caucuses. While it is not possible to identify American Jews as such in recent Censuses, it is possible to analyze recent Russian Jewish immigrants, as has been done using the 1980 to 2000 Censuses (Chiswick 1993, 1997b; Chiswick and Wenz 2006). During the late 1970’s and early 1980’s and again during the late 1980’s through the early 1990’s there was a substantial migration of refugees to the United States from the Former Soviet Union (FSU), although in the latter period there was a much larger flow from the FSU to Israel. Unlike the Russian Jewish immigrants from 1881 to 1924, who were Yiddish-speaking workers in sales, craft, and operative jobs before migrating, the newer influx spoke Russian and tended to be highly educated individuals who had worked in professional occupations.

For the purpose of analyzing the new influx of Russian Jews, the 2000 Census data was limited to immigrants who came to the United States since 1965, with Jews identified as those 
born in the former Soviet Union who were not of Armenian ancestry and did not report that the language that they spoke at home was Armenian or Ukrainian. ${ }^{30}$

Other variables being the same, the Russian Jewish immigrants in the 2000 Census had earnings lower than those of other European immigrants, but the earnings differences varied sharply by period of arrival and level of education (Chiswick and Wenz, 2006, Table 8). Among immigrants in general earnings increased with duration in the US, but this gradient was much steeper for the Russian Jews. While the earnings of Russian Jews who arrived in the US between 1965 and 1990 did not differ significantly from other European immigrants, the earnings of Russian Jews were lower among those who arrived more recently.

Analyses for the 1980 and 1990 Censuses also show recent Soviet Jewish arrivals having lower earnings than other European immigrants, with the differences in earnings diminishing and then disappearing with a longer duration. Thus, while recent immigrants from the Former Soviet Union had low earnings in the 1980 and 1990 Censuses, after being in the US 10 years they appear to have attained earnings parity with other European immigrants.

This pattern would be consistent with the refugee nature of the Russian Jews. They were fleeing religious/ethnic discrimination and for most the ability to leave and the timing was generally unexpected, and few had planned in advance for the move. The greater steepness of the increase in earnings with duration in the US is consistent with greater investments to increase

\footnotetext{
${ }^{30}$ Among the adult male immigrants in the US in 2000 who immigrated since 1965 from the Former Soviet Union, 41 percent reported their ancestry as Russian, 10 percent gave an ancestry response indicating a religion (specific religion masked by the Census Bureau), 11 percent reported Armenian, and 38 percent gave a variety of other responses. Of the languages spoken at home in the US, 4 percent reported only English, 72 percent Russian, 9 percent Armenian, 7 percent Ukrainian, and 8 percent other languages, of whom only 0.2 percentage points, primarily older men, reported Yiddish (Chiswick and Wenz, 2006, Table A-1).
} 
the transferability of their pre-migration skills, including language skills, or higher rates of return on post-immigration investments in skill, or both.

It is noteworthy that in spite of generally lower transferability to the US labor market of the skills of refugees than of economic migrants, Russian Jews in 2000 received a larger payoff from years of schooling than did other immigrant men (schooling coefficient 0.026 points, or 2.6 percent, which is higher than the 0.045 , or 4.5 percent, for other immigrants). As a result of the greater return from schooling, at the mean level of schooling among Soviet Jews (14.8 years), those in the US for 10 or more years had achieved earnings parity in 2000 with other European immigrants.

Thus, in spite of their refugee experience that put them at a substantial earnings disadvantage at arrival, compared with other European immigrants the Russian Jews experienced much more rapid improvements in their labor market earnings and greater returns from their schooling. By 2000, those who arrived in the US in 1990 or earlier with the mean level of schooling for Russian Jews had already attained earnings parity with other, primarily economic, European immigrants. It was the most recent arrivals and those with little schooling who were at the greatest earnings disadvantage.

\section{Wealth}

Occupational attainment and earnings reflect the human resources of a person - including schooling, job-related skills, decision making ability, and other related characteristics of the person, mitigated by the discrimination experienced. Yet, individual and household well-being is also reflected by the non-human assets that they own, referred to here as their wealth. Data on the wealth of American households are even more scarce than data on the occupation, earnings, or self-employment, and do not go back in time. Data on wealth that includes a method for 
identifying Jews, with a sufficiently large sample for statistical purposes, is even more scarce. Moreover, wealth data are plagued by far more measurement issues than are data on the occupation or earnings. The reporting of wealth is subject to much error, few know the true market value of their owner-occupied house, and even fewer know the asset value of their pension plans. Moreover, family or household composition affects wealth status.

It would be expected that contemporary American Jews would have a high level of financial wealth. The high occupational status and the high earnings would provide the resources for wealth accumulation. The high propensity for non-farm self-employment would also be conducive to wealth accumulation. Furthermore, the low fertility rate implies that the same parental wealth passed on to the next generation would mean a greater inheritance per child, facilitating the inter-generational transmission of wealth among Jews. If, as suggested above, Jews appear to be more responsive to economic opportunities they probably would also be more successful in wealth accumulation.

Keister (2005, Chapter 6) used the data from the National Longitudinal Survey of Youth (1979 cohort) to study the wealth 20 years later (2000) of respondents by the religion in which they were raised. While she found that the median net worth for all families in these data was $\$ 58,000$ in 2000 , for Jews it was $\$ 221,000$. Among the religious groups identified, the next highest wealth holders were the Episcopalians with a median wealth of $\$ 120,000$. Among the groups studied, Jews had the smallest proportion of those with zero or negative net worth. Jews were more likely than any of the other religion groups identified to: own their own home, own stocks or bonds, have a checking or savings account, and own business assets. Reflecting inheritance patterns, Jews were more likely to have a trust account. 
Other determinants of wealth the same, including level of schooling, those who were raised Jewish had a higher level of wealth, and were more likely to own stocks (Keister 2005, Chapter 6). They were more likely to have a trust account and to have inherited assets, measures of intergenerational wealth transfers. In contrast to the simple pattern, when other measured variables are the same, such as schooling, Jews were less likely to own their own home. This may arise from the study not controlling statistically for urban residence, particularly residence in New York City. Home ownership is lower in urban areas in general and in New York City in particular, and Jews are a highly urbanized population. It may also reflect a substitution of investments in financial assets over investments in an owner-occupied dwellings among Jews of the same level of schooling as non-Jews. The extent to which American Jews have a higher savings rate or earn a higher return on their investments has not been studied.

The high level of wealth among Jews, perhaps in part due to a greater responsiveness to economic incentives, helps finance the high level of education in the next generation, and hence the high occupational attainment and earnings of their children, as well as their children's financial assets. Thus there is a greater inter-generational transmission of human and non-human resources among Jews compared to those who are not Jewish.

\section{Summary and Conclusion}

The occupational patterns of American Jews were influenced by the occupations that they had prior to migration to the US and the employment opportunities that they experienced once settled in this country. The Jews of Colonial America concentrated on the eastcoast seaport cities and specialized in local, interior, costal, and international trade and finance. The mid-19 ${ }^{\text {th }}$ century German Jewish immigrants spread across the country, specializing in clerical and sales 
jobs in retail trade, often starting as peddlers. Some progressed to owning and managing large and prominent department stores.

The late $19^{\text {th }}$ and early $20^{\text {th }}$ century East European and Russian Jewish immigrants concentrated in New York City and other emerging industrial centers. They started in craft, operative, and laborer jobs, but if not they then their children advanced to higher level occupations. By mid-20 $0^{\text {th }}$ century many were employed in managerial and professional occupations. At the turn of the $21^{\text {st }}$ century half of Jewish men and women were in professional jobs, compared to only one-in-five among non-Jewish white men and women.

Although few Jews were farmers, throughout their experience in the United States Jews have had a high rate of self-employment. However, the nature of the self-employment did change. Among the mid- $19^{\text {th }}$ century German Jews self-employment in the retail sector predominated. Among the East European and Russian Jews in the early $20^{\text {th }}$ century light manufacturing (e.g. garment industries) and retail trade were the primary industrial sectors for the self-employed. Later self-employment among professionals came to be an important activity.

Although limited, data over the $20^{\text {th }}$ century permit comparing the earnings of Jews and others in the same data set, thereby assuring comparability of the measures under study within each period. These analyses find substantially higher earnings among Jewish men than other white men overall, and even after controlling for the major determinants of earnings, including years of schooling. The differential appears to be at least 16 percent, ceteris paribus. When another measure of labor market outcomes, major occupational group, is held constant the differential among men falls to about 8 to 10 percent. Yet, differentials of these magnitudes are the economic equivalent of about two extra years (or when major occupation group is held 
constant, one extra year) of schooling. This is in addition to the higher educational attainment of Jewish men and women.

The analyses of earnings suggest that Jews receive a higher economic return from their years of schooling. This may contribute to their obtaining higher levels of schooling. The earnings data also suggest that Jews have a more elastic labor supply curve, that is, that higher wages have a greater impact on increasing employment among Jews. This suggests a greater sensitivity to economic opportunities. Moreover, Jewish immigrants appear to have a steeper increase in earnings with duration in the US than do other immigrants. Taken together these patterns in earnings suggest that Jews make greater investments in their human capital relevant for the labor market, that they receive greater returns from human capital investments, and that they appear to be more responsive to economic incentives than are others.

Data on wealth are much more limited, and wealth is measured with greater error than is occupation or earnings. Data for adults in the year 2000 suggests that those raised Jewish have a much higher level of wealth (measured by financial assets, business assets, and the value of real estate or housing assets) than those raised in another religion. Wealth among Jews is even greater than among the next wealthiest religious group, the Episcopalians. This holds true even when other measured variables are held constant. The data suggest a higher rate of accumulation of assets, a higher level of wealth, and a greater inter-generational transmission of wealth. These patterns may be reflecting a greater ability to discern and a greater responsiveness to opportunities for wealth accumulation, a greater willingness to take economic risks, and a higher savings rate.

There are several lessons to be drawn from the economic experience of American Jewry. One is that Jews sought out niches in the labor market in which they would be subject to less 
discrimination. Some of these niches were in "socially suspect" occupations, such as in entertainment, including the emerging movie industry in the early decades of the $20^{\text {th }}$ century. When rewarding sectors opened up, Jews entered them.

A second was the application of entrepreneurial and decision-making skills. From the Colonial Jewish merchants and financiers to the German Jewish shop owners, to the present managers and professionals, Jews demonstrated a capacity for successful entrepreneurial activity. It may be debatable whether the Jews "made" the garment industry or the movie industry or whether these industries "made" the Jews, but there is no debate that the Jews identified and entered emerging economic sectors.

A third is that Jews placed high value on learning the skills necessary for advancement given the time and place. In $20^{\text {th }}$ century America that meant schooling, and Jews placed an emphasis on achieving high levels of formal education. For some this meant battling discrimination directly, for some it meant finding ways to avoid discrimination in the US (e.g., studying medicine abroad), for some it meant masking or even denying their Jewish religion, heritage, or identity, but for most it meant taking advantage of existing educational and employment opportunities in the United States.

Thus, it appears that American Jews have not achieved a higher occupational status through a sacrifice of earnings, but rather they have achieved both high earnings and high occupational status simultaneously. Moreover, their greater labor market achievements do not appear to have retarded their wealth accumulation, but rather appear to have advanced it. Throughout their 350 year presence in the United States, American Jews have demonstrated extraordinary economic achievements. 


\section{REFERNCES}

Alchian, Armen A. and Reuben A. Kessel. (1962), "Competition, Monopoly, and the Pursuit of Money” in National Bureau of Economics Research, Aspects of Labor Economics, Princeton University Press.

Barkai, Avraham. (1986). "German Jewish Migration in the Nineteenth Century, 1830-1910" in Ira A. Glazier and Luigi DeRosa, eds., Migration Across Time and Nations: Population Mobility in Historical Contexts. New York: Holmes and Meier, pp. 202-219.

Billings, John S. (1890). Vital Statistics of Jews in the United States. Census Bulletin, No. 19, Washington, DC, December 30, 1890.

Blake, Kellee. (1996). "First in the Path of the Fireman: The Fate of the 1890 Population Census," Prologue, (Spring): pp. 64-81.

Chiswick, Barry R. (2009). “The Rise and Fall of the American Jewish PhD,” Contemporary Jewry, 29(1), April, pp. 67-84.

Chiswick, Barry R. (2007) “The Occcupational Attainment and Earnings of American Jewry: 1990-2000,” Contemporary Jewry, 27, pp. 80-111.

Chiswick, Barry R. (2001). "The Billings Report and the Occupational Attainment of American Jewry, 1890," Shofar: An Interdisciplinary Journal of Jewish Studies, 19(2), Winter, pp. 5375.

Chiswick, Barry R. (1999) “The Occcupational Attainment and Earnings of American Jewry, 1890-1990,” Contemporary Jewry, 20, pp. 68-98.

Chiswick, Barry R. (1997a). "Working and Family Life: The Experience of Jewish Women in America” in Sergio DellaPergola and Judith Evans, eds. Papers in Jewish Demography, Jerusalem: Hebrew University, Institute of Contemporary Jewry: pp. 277-287.

Chiswick, Barry R. (1997b). "Soviet Jews in the United States: Language and Labour Market Adjustments Revisited," in Noah Lewin-Epstein, Yaacov Ro'i and Paul Ritterband, eds., Russian Jews on Three Continents: Migration and Resettlement, London: Frank Cass Publishers, 1997, pp 233-260.

Chiswick, Barry R. (1995) "The Skills and Economic Status of American Jewry" in Robert S. Wistrich, ed. Terms of Survival: The Jewish World Since 1945, London: Routledge, pp.115-129.

Chiswick, Barry R. (1993). "Soviet Jews in the United States: An Analysis of their Linguistic and Economic Adjustment" International Migration Review, 27(2), Summer, pp. 260-286. 
Chiswick, Barry R. (1992). "Jewish Immigrant Wages in America in 1909: An Analysis of the Dillingham Commission Data" Explorations in Economic History. 29(3), July, 274-289.

Chiswick, Barry R. (1986). "Labor Supply and Investment in Child Quality: A Study of Jewish and Non-Jewish Women," Review of Economics and Statistics, November 1986, pp. 700703.

Chiswick, Barry R. (1983) "The Earnings and Human Capital of American Jews," Journal of Human Resources, 18(3), Summer, pp. 313-336.

Chiswick, Barry R. and Michael Wenz. (2006). "The Linguistic and Economic Adjustment of Soviet Jewish Immigrants in the United States: 1980 to 2000”, Research in Labor Economics, 24, pp. 179-216.

Chiswick, Carmel U. (2007) “Occupation and Gender: American Jews at the Millenium,” Paper presented at the Seminar on Creating and Maintaining Jewish Families, Waltham: Brandeis University, March.

Darvish, Tikva. (1985). "The Economic Structure of the Jewish Minority in Iraq vis-a-vis the Kuznets Model," Jewish Social Studies. 47, no. 3-4 (Summer-Fall): pp. 255-266.

DellaPergola, Sergio. (2003). “World Jewish Population,” American Jewish Yearbook, New York: American Jewish Committee.

Dinnerstein, Leonard. (1994), Anti-Semitism in America, New York: Oxford University Press.

Douglas, Paul H. (1919), “Is the New Immigration More Unskilled Than the Old?” Journal of the American Statistical Association, June, pp. 393-403 (p 393).

Elazar, Daniel J. with Peter Medding. (1983). Jewish Communities in Frontier Societies: Argentina, Australia and South Africa, New York 1983: Holmes and Meier.

Gartner, Lloyd P. (1983), "Immigration and the Formation of American Jewry, 1840-1925," in Marshall Sklare, ed. American Jews: A Reader. New York: Behrman House: 3-22.

Glenn, Susan A. (1990) Daughters of the Shtetl: Life and Labor in the Immigrant Generation Ithaca: Cornell University Press.

Goodman, Abram V., editor, (1951), “A Jewish Peddler’s Diary, 1842-1843,” American Jewish Archives, Vol. 3, June: pp. 81-109.

Hartman, Harriet and Moshe Hartman. (2009). Gender and American Jews, Waltham: Brandeis University Press.

Hartman, Moshe and Harriet Hartman. (1996). Gender Equality and American Jews. Albany, NY: State University of New York. 
Himmelfarb, H.S., R.M. Loar, and S.H. Mott (1983). “Sampling by Ethnic Surnames: The Case of American Jews” Public Opinion Quarterly, 47, pp. 247-260.

Keister, Lisa (2005). Getting Rich: America's New Rich and How They Got That Way. New York: Cambridge University Press.

Kohler, Max J. (1901). "The German-Jewish Migration to America" Publications of the American Jewish Historical Society. No.9, pp.87-105.

Korbin, Frances E. (1983). "National Data on American Jewry, 1970-71: A Comparative Evaluation of the Census Yiddish Mother Tongue Sub-population and the National Jewish Population Survey" in U. O. Schmelz, et al., eds., Papers in Jewish Demography 1981. Jerusalem: Hebrew University Institute of Contemporary Jewry: pp. 129-43.

Lestschinsky, Jacob. (1966). "Jewish Migrations, 1840-1956" in Louis Finkelstein, ed. The Jews: Their History, Culture and Religion. Vol. II. Third Edition, Philadelphia, PA: Jewish Publication Society of America: pp. 1536-1596.

Marcus, Jacob Rader. (1990). To Count a People: American Jewish Population Data, 15851984. Lanham, MD: University Press of America.

Marcus, Jacob Rader. (1970). The Colonial American Jew 1492-1776, Detroit: Wayne State University Press.

Prais, S.J. and Marlena Schmool. (1975). "The Social Class Structure of Anglo Jewry, 1961," Jewish Journal of Sociology. 16 (June): pp. 5-15.

Ritterband, Paul .(1998). "Counting the Jews of New York, 1900-1991: An Essay in Substance and Method." Department of Sociology, University of Haifa, September.

Ritterband, Paul and H.S. Wechsler. (1994), Jewish Learning in American Universities: The First Century, Bloomington: Indiana University Press.

Rosenthal, Erich. (1975). "The Equivalence of United States Census Data for Persons of Russian Stock or Descent with American Jews." Demography. (May): pp. 276-290.

Rosenwaike, Ira. (1971). "The Utilization of Census Mother Tongue Data in American Jewish Population Analyses." Jewish Social Studies. April/July: pp. 141-59.

Sarna, Jonathan (2004). American Judaism: A History, New Haven: Yale University Press.

Sheskin, Ira M. (1998). “A Methodology for Examining the Changing Size and Spatial Distribution of a Jewish Population: A Miami Case Study,” Shofar: An Interdisciplinary Journal of Jewish Studies, 17(1), Fall, pp. 97-116. 
Syrquin, Moshe. (1985). "The Economic Structure of Jews in Argentina and Other Latin American Countries," Jewish Social Studies. 47, no. 2 (Spring): pp. 115-134.

Tomes, Nigel (1983) "Religion and the Rate of Return on Human Capital: Evidence from Canada,” Canadian Journal of Economics, February, pp. 122-138.

U.S. Bureau of the Census. (no date). "Tabulations of Data on the Social and Economic Characteristics of Major Religious Groups, 1957," Washington, DC, mimeo.

U.S. Bureau of the Census. (1989). 200 Years of U.S. Census Taking, Population and Housing Questions. 1790-1990. Washington, DC.

U.S. Bureau of the Census. (1958). "Religion Reported by the Civilian Population of the United States: March 1957," Current Population Reports, Population Characteristics. Series P-20, No. 79, February 2, Washington, DC.

U.S. Census Office. (1897). Report on Population of the United States at the Eleventh Census: 1890, Part II, Department of the Interior, Washington, D.C., U.S. Government Printing Office.

U.S. Immigration Commission. (1911). Reports of the Immigration Commission. Vol. I to 41. Washington, DC: U.S. Government Printing Office. 